\title{
Contextual Learning Strategy (CTL) on Mufradat Learning in IV Class of Madarasah Ibtidaiyah
}

\author{
Nurul Hidayah ${ }^{1}$ Zulhadi $^{2}$ \\ ${ }^{1,2}$ Arabic Language Education, Mataram State Islamic University, Indonesia \\ hidavahnurul0202@gmail.com, zulhadi@gmail.com
}

\begin{abstract}
Keywords:

Strategy Learning, CTL,

Mufradat Learning.

This research aims to know the process of Mufradat learning using CTL strategy in class IV MI Riadusholihin Tohir Yasin. This form of research is qualitative descriptive. Data collection methods for observation, interviews and documentation. While the analysis used is qualitative data analysis. The result of this research is the implementation of the learning of Mufradat with the CTL strategy to produce effective and efficient learning, with the steps IV Teacher class Riadussholihin Thohir Yasin set up the CTL hand out which includes: a) teachers divide the students into 2 groups according to the number of students. b) Each group is assigned to compose and attach a randomized hiwar on the cardboard that has been given by the teacher. c) Students who have more mistakes in drafting Hiwar are lost in completing the task given by the teacher and given the sanction of the winning group, namely giving each 3 Mufrada about the Isim Dhomir to be answered by the losing group. D) The winning student is entitled to a prize on condition after successfully mentioning 3 Mufradat about the Isim Dhomir he knows. e) Teachers help students conclude their group's work on the Hiwar they have learned. The use of CTL learning strategies in Mufrodat learning in class IV MI Riadusshalihin Tohir Yasin gives quite good results, according to the student's condition and in accordance with the purpose of learning Arabic IV MI Riadusshalihin Tohir Yasin but still need to improve the implementation steps of CTL Learning strategy and habituation of use of the method to get maximum results and minimize the value of the incomplete.
\end{abstract}

\section{Article History:}

Received: 27-06-2019

Revised : 19-08-2019

Accepted: 28-08-2019

Online : 30-08-2019

This is an open access article under the CC-BY-SA license
crossret
https://doi.org/10.31764/ijeca.v2i2.2104

\section{A. INTRODUCTION}

Learning is the process, the way, the deeds that make learning activities. From this definition can be concluded that learning is the process of student interactions and educators in a learning environment.

According to Wina Sanjaya, one of the problems facing the world of education today is the weakness of the learning process (Sanjaya, 2010). In the learning process, children are less encouraged to develop thinking skills. The learning process in the classroom is directed toward the ability of the child to memorize information, the child's brain is forced to remember and hoard a variety of information without being required to understand the desired information to connect it with daily life. As a result when students graduate from school, they are smart theoretically, but they are poor applications. 
Based on the above statement, how is the education process that is supposed to achieve educational objectives for teachers and students or education standards. In the learning process, should achieve a teaching purpose. The purpose of this teaching can be seen from the change of students after the learning process, such as the aspect of behavior, the increasing knowledge, the ability to develop, essentially the change that tends to be positive.

From this view, it can be drawn a conclusion that learning is not merely the process of transforming the science of a teacher to learners who impressed only the process of communication one way, but more than that, learning requires a teacher to be able to create and make the participants to learn and become an active in the learning process to happen a "take and give" process. Therefore, a teacher must have a technique and a way to motivate learners to learn. One of the most common ways teachers have to spark the spirit of the participants to learn is to design a specific learning strategy.

The learning strategy is interpreted as "a plan, method, or series of activities designed to achieves a particular educational goal" (Sanjaya, 2010). Thus, the learning strategy can be interpreted as planning that contains a series of activities designed to achieve specific educational objectives. There are several learning strategies that can be used in the learning process including: Learning strategies based on components in the teaching program, learning strategies based on message or material processing activities, learning strategies based on message processing or learning materials and strategies based on how memperoses discovery (Sunendar, Cahyani, \& Mulyadi, 2014). CTL is a type of learning strategy based on the emphasis of components in teaching programs. In addition, CTL is a learning strategy that engages students fully in the learning process. Students are encouraged to study lesson materials according to the topics they learn. In this study devoted to the learning of mufradat (vocabulary). This CTL type learning strategy is suitable applied to the Mufradat (vocabulary) lesson because the Mufradat (vocabulary) is one of the language elements that must be mastered by foreign language learners to acquire the skills of communicating with the language (Effendy, 2002). The important thing that a teacher should be aware of in a mufradat lesson is that he has to prepare the right vocabulary for his students, because of the lack of understanding of a teacher's strategies and ways of teaching mufradat on his students, so that many of the Mufradat learning processes are less than the maximum even failure.

Based on the initial observation conducted by researchers at Madrasah Ibtidaiyah Riadusholihin Tohir Yasin, researchers found that the learning activities of mufradat (vocabulary) with a strategic strategy (CTL) had not been conducted by the Arabic language teacher. Therefore, researchers are interested in choosing the title "Contextual learning Process (CTL) on Mufradat Learning (vocabulary) in class IV of Madrasah Ibtidaiyah Riadusholihin Tohir Yasin".

\section{B. METHODS}

The implementation of this research uses a qualitative approach. In the implementation of this research researchers use a qualitative approach, because the data that researchers acquire in the field is the data that is information or description related to the existing titles not in the form of symbols or numbers. In this study, researchers used a qualitative descriptive approach. In other words, the researcher only exposes and explains what it is about the facts at the research site in the form of writing. Literally, descriptive research is a study that intends to make descriptions of situations or events. In the sense that descriptive research is the accumulation of basic data in a descriptive way simply do not have to seek or describe mutual relationships, test hypotheses, make predictions, or gain meaning, and the implications though research aimed at finding such things can include also a descriptive method. (Suryabrata, 2003). The data collection techniques used are observation, interviews and documentation (Sugiyono, 2016), 
while the research object in this study is all IV students of MI Riadussholihin Thohir Yasin who amounted to 9 people.

\section{RESULT AND DISCUSSION}

Contextual learning is a learning that associates learning materials with real-world context that students face in their daily environment, society, the environment and the workforce, so that students are able to make a relationship between his knowledge with his application in daily life, involving seven key components of learning: countermeasure (constructivism), inquire (questioning), investigate (inquiry), Learning Community, modeling, Reflection (reflection) , and authentic Assessment. (Majid, 2013)

Arabic language learning at MI Riadusholihin Thohir Yasin has the purpose of organizing contextual learning (CTL) in each process of the learning, the implementation of the CTL is one of the efforts used to make the lesson feel meaningful for students in learning Arabic. A contextual approach (Contextual Teaching and Learning/CTL), according to Hernowo is a learning system based on the philosophy that a learner will be able to absorb the subject matter if they can capture the meaning of the lesson. The learning process will take place more naturally in the form of activities students work and experience, not the transfer of knowledge from teachers. With this concept, learning outcomes are expected to be more meaningful for students to solve problems, think critically.

Of the many learning models in this CTL, the Arabic teacher in class IV MI Riadusholihin Thohir Yasin chose not to use the CTL learning models because of all these CTL models have the level for implementing them, the level in question based on the student's age and the student's condition, therefore the teacher only implements the omponents contained in this CTL study and the Arabic language teacher is more emphasis on the question, an example of using a simple question that was applied in class IV Arabic teachers only during today's aperittions on Arabic language and subsequent meetings teachers plan to use CTL learning strategy type question back on Hiwar material, teacher fishing students to answer simple questions surrounding the mufradat and its meaning, the question rules start from the teacher asking one of the students what the Mufradat of the objects contained in the class, then after the student successfully answered correctly, students are given the opportunity to ask questions about the Mufradat different from the previous to one of the other friends who of course he must know the meaning of the Mufradat asked for his friend, this probing lasts for 5 minutes after the teacher feel enough to refresh the memory of students to the mufradat that they have noted earlier.

The basic material that has been established from the package book discusses Hiwar with the structure of Isim Dhomir, therefore the mufradat that researchers observed in this study is about Isim Dhomir. In applying CTL in the Mufradat learning process, Arabic language teachers in class IV MI Riadhussholihin Thohir Yasin perform the following steps:

\section{Planning}

The CTL strategy implementation was held on September 3, 2014, teachers remind students of today's lesson is discussing Hiwar with the structure of Isim Dhomir, to add to the students ' understanding of the Isim Dhomir, the teachers have the initiative to make the atmosphere of the class more meaningful by dividing the pupils into 2 groups namely Banin and Banat. The atmosphere of different learning conditions shows a learning arena that is influenced by 
emotions, and including emotions in learning is one of the supporting factors in achieving the goal of a learner (Purwanto, 2011).

a. In fact, the Arabic teacher in class IV MI Riadussholihin Thohir Yasin, always put together a learning implementation plan (RPP) as a sign-up for the learning process, using props relevant to the teaching materials, implementing the learning process according to RPP and conducting evaluation activities to measure the level of students ' understanding of the material that has been taught.

b. Following signs in general in implementing the learning process using the CTL strategy, which should be considered in the preparation of contextual learning plans is as follows: a). Declare the first activity of the study, which is a statement of student activity which is a combination of: competency standards, basic competencies, subject matter, and achievement of learning outcomes. b). State the general purpose of the lesson. c). Details of the media to support the activity. d). Create step-by-step student activity scenarios. e). Declare authentic Assessmentnya, that is, with what data students can observe his participation in learning.

c. Referring to the signs of making the program, the teacher prepares a personal hand out, therefore this hand out only contains the important points of the CTL strategy of the type question teachers used in the field of study. Unlike the implementation plan of the (RPP) is made in detail. The following hand out is prepared by class IV Arabic teacher MI Riadussholihin Thohir Yasin: Teachers divide students into 2 groups according to the number of students

d. Each group is tasked to compose and attach a randomized hiwar on the cardboard that has been given by the teacher.

e. Students who have more mistakes in drafting Hiwar are lost in completing the task given by the teacher and given sanctions from the winning group, namely giving each of the three mufradat about the Isim Dhomir to be answered by the losing group.

f. The winning students are entitled to prizes on a condition after successfully mentioning 3 Mufradat about the Isim Dhomir he knows.

g. Teachers help students conclude their group's work on the Hiwar they have learned.

\section{Actions}

The implementation of this action began on September 10, 2014, and researchers watched the teachers start from when entering classes until the class, at that time teachers start the lead by leading the prayer, from the religious side is aimed to get the blessing of knowledge obtained and can be utilized in the future, while in terms of psychology, pray can calm the heart and mind so that the students start a job has readiness to follow the process of learning, because in each prayer contains hopes, intentions and beliefs to obtain all good.

After the prayer of teachers continue with the attendance of students while detecting the passion of students in learning, if there are indications of weakness/not passionate to study, teachers start the first step by telling a funny example story like the story of Abu Nawas, this exemplary story can lure laughter/joy in the students so that they can learn by involving emotions. But if the teacher finds no indication, the teacher continues the learning activities by conveying the scope of Hiwar material, the structure contained, competency standards, basic competencies, learning objectives that will be achieved in the learning activities and inform that the intelligence test on this material with two tasks that are group and individual tasks. 
Furthermore, the teacher begins the lesson by reading Hiwar and asking the students to listen and pay attention to the Hiwar readings in the book LKS (student worksheets). This is done by the teacher to model the way to read Hiwar with a clear intonation and affirm Makhorijul letters well and correctly, because basically for students in this class IV has a psychology development that is still in The imitation stage (imitating) so it is not difficult for them to impersonate the intonation or makhorijul letters that are heard. In addition, to familiarize students with the words that speak Arabic so they do not feel unfamiliar with the Arabic sentences that they come across.

After reading Hiwar, the teacher rewrites the important hiwar-hiwar that often happens in their real life and its mufradat and meaning. After the students have finished writing the teachers who have recorded the dips, the teacher explained again with a simple example of conversation and tried to involve the students in answering the question the teacher asked. After the students understood the Hiwar, the teacher showed the form of the Isim Dhomir which was found in a hiwar sentence and wrote the whole Isim Dhomir in addition to their notes.

The question is retold to all other students to familiarize them with answering questions that are similar to good and correct. Naturally the teacher explains the final line difference when opening Hiwar with the opposite gender.

In this core activity held on 17 September, at this meeting the teacher asked the students to sit in accordance with the group that had been shared before, then handed over the sheet that was in the form of cardboard paper and several pieces of words and their meanings to both groups. After the student is ready with his group, the teacher instruces to start discussing and compiling the word pieces into a hiwar as they have already learned.

Teachers choose the form of group work as evaluation of the learning because in the discussion contains elements of communication/interaction. It is essentially a social process, i.e. something that lasts or walks between people (Huda, 2017). Also teachers believe in discussions creating positive emotions, brain research is increasingly demonstrating the relationship between emotional involvement, long-term memory and learning. Dr. Daniel Goleman explains "Arguably, we have two brains, two choices, and two intelligences, a life and learning gait is determined by both, not just the IQ, but the acting emotional intelligence, of course intellect cannot work at its peak without emotional intelligence"(Rosidin, 2018).

From the theory above the researchers concluded that as a social process, in the communication occurred individual interactions with the environment and emotional medicine. This is what eventually led to the process of changing attitudes from not know to know and from not understand to be understood.

In the final learning activities, teachers ensure that each group member has completed its citizens, which is to compose pieces of word into a hiwar and ready to run the Sanki that has been agreed together.

\section{Evaluation}

For assessment of learning results Teachers use authentic assessement (real assessment). There are four categories of assessment; Comprehensive portfolio, performance measurements, projects and answers (Jhonson, 2006). In this case the teacher chooses the category of the project, because the project category is worth the task of the group that must accomplish the task that the teacher has ordered.

The group task that teachers give is to compose and paste a randomized hiwar on cardboard and be willing to accept sanctions. And for individual duties at the time of the 
sanctions are the students who lose in completing the task given by the teacher, as well as for the group who won will get a prize if the successful mention each of the 3 mufradat about the Isim Dhomir that they know. From the evaluation of students, the following:

Table 1. List of student values MI Riadussholihin Tohir Yasin

\begin{tabular}{clcc}
\hline No & \multicolumn{1}{c}{ Name } & Value & Description \\
\hline 1 & Aly Ramdani Al-jufri & 100 & Complete \\
\hline 2 & Gus Wardi & 60 & Complete \\
\hline 3 & Husnan & 20 & Incomplete \\
\hline 4 & Lia Andriani & 50 & Incomplete \\
\hline 5 & Rayhan Arya Pertama & 50 & Incomplete \\
\hline 6 & Siti Bulan Faoziah & 80 & Complete \\
\hline 7 & Sumidah & 40 & Incomplete \\
\hline 8 & Ifan Juliadi & 60 & Complete \\
\hline 9 & Bq. Riska Izzati Gunawan & 60 & Complete \\
\hline
\end{tabular}

Based on the data exposure of the research results that the level of understanding students in class IV MI Riadusshalihin Tohir Yasin, especially in Arabic subjects are good enough. As for the average student value prescribed by the teacher of the field of Arabic language study is 60 this indicates that the grade IV students are good enough in learning Arabic. The implementation of the learning process at MI Riadusshalihin Tohir Yasin implemented in accordance with the steps in implementing this contextual strategy but there are some components and elements that teachers are less concerned about the results in applying the strategy is less maximal.

\section{CONCLUSION AND SUGGESTIONS}

Based on the findings of the data and the discussion of the research results that have been described, according to the focus of the problem studied, it can be concluded that the process of implementing Mufradat learning with CTL strategy goes effective and efficient, class IV teachers Riadussholihin Thohir Yasin previously prepared a CTL hand out which includes b) Each group is assigned to compose and attach a randomized hiwar on the cardboard that has been given by the teacher. c) Students who have more mistakes in drafting Hiwar are lost in completing the task given by the teacher and given the sanction of the winning group, namely giving each of the three mufradat about the Isim Dhomir to be answered by the losing group. D) The winning student is entitled to a prize on condition after successfully mentioning 3 Mufradat about the Isim Dhomir he knows. e) Teachers help students conclude their group's work on the Hiwar they have learned. The use of CTL learning strategies in Mufrodat learning in class IV MI Riadusshalihin Tohir Yasin gives quite good results, according to the student's condition and in accordance with the purpose of learning Arabic IV MI Riadusshalihin Tohir Yasin but still need to improve the implementation steps of CTL Learning strategy and habituation of use of the method to get maximum results and minimize the value of the incomplete.

\section{REFERENCES}

Effendy, A. F. (2002). Sekilas Tentang Madah Nabawi Dalam Kesusastraan Arab. Prosiding Seminar Akademik, 2, 65-79. Retrieved from http://sastra.um.ac.id/wp-content/uploads/2009/10/Sekilastentang-Madah-Nabawi-dalam-Kesusasteraan-Arab-A.-Fuad-Effendy.pdf

Huda, N. (2017). Manajemen Pengembangan Kurikulum. Al-Tanzim : Jurnal Manajemen Pendidikan Islam, 1(2), 52-75. https://doi.org/10.33650/al-tanzim.v1i2.113

Jhonson, B. E. (2006). Contextual Teaching and Learning (CTL). In Jurnal ekonomi \& pendidikan. https://doi.org/10.1145/1028664.1028744

Majid, A. (2013). Strategi Pembelajaran (2nd ed.). Bandung: PT Remaja Rosdakarya. 
Purwanto, N. (2011). Prinsip-prinsip dan Teknik Evaluasi Pengajaran. In PT Remaja Rosdakarya.

Rosidin, M. (2018). Relasi Dan Rekonsiliasi Antara Pendidikan Islam Dengan Pendidikan Barat. Journal EVALUASI, 1(2), 235. https://doi.org/10.32478/evaluasi.v1i2.75

Sanjaya, W. (2010). Strategi Pembelajaran Berorientasi Standar Proses Pendidikan. System, Vol. 6, pp. 140-151.

Sugiyono. (2016). Memahami Penelitian Kualitatif. Bandung: Alfabeta.

Sunendar, D., Cahyani, D., \& Mulyadi, Y. (2014). Jurnal bahasa \&amp; sastra. In Jurnal Pendidikan Bahasa $\begin{array}{lllll}\text { dan } & \text { Sastra } & \text { (Vol. } & 14) . & \text { Retrieved }\end{array}$ http://ejournal.upi.edu/index.php/BS_JPBSP/article/view/721/521

Suryabrata, S. (2003). Metode Pene-litian. Jakarta: PT. Raja Grafindo Persada, 36-44. 